ENTREPRENEURSHIP AND SUSTAINABILITY ISSUES

ISSN 2345-0282 (online) http://jssidoi.org/jesi/

2020 Volume 7 Number 4 (June)

http://doi.org/10.9770/jesi.2020.7.4(16)

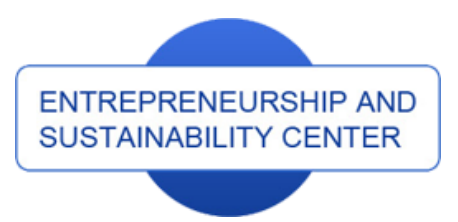

Publisher

http://jssidoi.org/esc/home
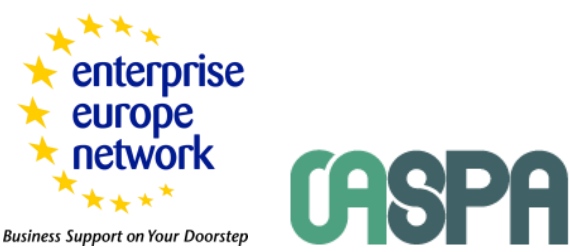

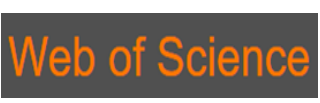

Clarivate

Analytics

\title{
THE INFLUENCE OF CORPORATE GOVERNANCE MECHANISM ON THE INTEGRATED FINANCIAL REPORTING AND INVESTMENT RISK OF THAI LISTED COMPANIES*
}

\author{
Sarapee Chanatup ${ }^{1}$, Somnuk Aujirapongpan ${ }^{2 *}$, Supit Ritkaew ${ }^{3}$ \\ ${ }^{1}$ Faculty of Management Sciences, Surathani Rajabhat University, 84000, Surat Thani, Thailand \\ ${ }^{2,3}$ School of Management, Walailak University, 80161, Nakhon Si Thammarat, Thailand

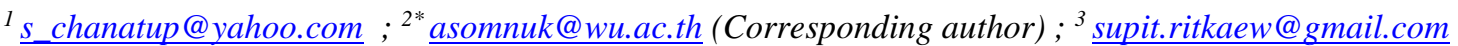

Received 16 July 2019; accepted 15 March 2020; published 30 June 2020

\begin{abstract}
This study was to examine relationships between corporate governance mechanism, integrated financial reporting, and investment risk on the stock exchange in Thailand. This study has investigated determinants and consequences of integrated financial reporting by analyzing Form 56-1 for year-end 2015 of the 240 Thai listed firms. To examine the relationship, an integrated financial reporting checklist was developed to identify the level of integrated reporting of listed firms on the Stock Exchange of Thailand. An index was based on seven dimensions of the International Integrated Reporting Framework. An integrated financial reporting is then analyzed using content analysis. An integrated financial reporting and corporate governance mechanism were collected from Form 56-1 for year-end 2015. Investment risk data was collected from SETSMART database. The analysis was conducted using structural equation modeling (SEM). The statistical results from factor analysis found that all seven dimensions are appropriate measurements of integrated financial reporting. The empirical result is that positive relationships were found for stakeholder-oriented corporate governance mechanism, shareholder-oriented corporate governance mechanism and integrated financial reporting; integrated financial reporting and investment risk. The model identified mediating relationship of integrated financial reporting between shareholder-oriented corporate governance mechanism and investment risk.
\end{abstract}

Keywords: corporate governance; integrated reporting; integrated financial reporting; investment risk

Reference to this paper should be made as follows: Chanatup, S., Aujirapongpan, S., Ritkaew, S. 2020. The influence of corporate governance mechanism on the integrated financial reporting and investment risk of Thai listed companies. Entrepreneurship and Sustainability Issues, 7(4), 2818-2831. http://doi.org/10.9770/jesi.2020.7.4(16)

JEL Classifications: E22, G34, M40

\footnotetext{
* This research was partially supported by the new strategic research $(P 2 P)$ project, and it also was supported by Institute of Research and Innovation, Walailak University, Thailand.
} 


\section{ENTREPRENEURSHIP AND SUSTAINABILITY ISSUES}

ISSN 2345-0282 (online) http://jssidoi.org/jesi/

2020 Volume 7 Number 4 (June)

http://doi.org/10.9770/jesi.2020.7.4(16)

\section{Introduction}

This paper studies the determinants and consequences of the integrated financial reporting (IFR) on Investment Risk in Thailand. Integrated financial reporting may be briefly defined as "a process founded on integrated thinking that results in a periodic integrated report by an organization about value creation over time and related communications regarding aspects of value creation." Where an annual integrated report "communicates an organization's strategy, governance, performance, and prospects in the external environment" (International Integrated Reporting Council [IIRC], 2013). Integrated financial reporting was first initiated in 2009 by Prince Charles, the Prince of Wales, and the International Federation of Accountants (IFAC), The Global Reporting Initiative (GRI) and other parties. They established the International Integrated Reporting Council (IIRC) in 2009 and published a framework in December 2013. The number of corporations applying integrated reporting remained relatively low during the early years, but this was followed by a rapid surge in popularity between 2009 and 2012. However, the level of integrated reporting then went into a period of decline after they published a framework in December 2013. It might be that the framework was confusing for the companies (Demirel \& Erol, 2016).

The integrated reporting principle adoption varied widely in developed countries (Demirel \& Erol, 2016). It is just beginning to permeate into Southeast Asia (e.g., Malaysia, Singapore, and Thailand). Graham (2014) suggested that the principal's adoption in developing countries should be studied due to their low integrated reporting. Especially in Thailand, the Securities and Exchange Commission announced in 2015 that corporate reports of listed companies should integrate non-financial and financial information. That is the first step to integrated reporting in Thailand. However, some organizations are struggling to determine whether their statements are integrated ones. That's why, the integrated reporting in Thailand has proved to be a somewhat complicated distinction in reporting practice, as well as, the emergence and effects of integrated financial reporting in Thailand.

\section{Literature review}

\section{Background of Integrated Reporting}

European enterprises were the first to adopt integrated reporting in 2002, followed by American companies in 2008 and South African listed firms in 2010 (Abeysekera, 2013; Eccles \& Saltzman, 2011). However, there remained ambiguity and a lack of clarity over the definitions, framework, and standards of integrated reporting. Some of the international organizations and famous scholars developed different integrated reporting definitions. For instance, the Integrated Reporting Committee (IRC) describes integration as "a holistic and integrated representation of a company's performance regarding both finance and sustainability" (IRC, 2011). In addition, IIRC defines integrated reporting as "a process founded on integrated thinking that results in a periodic integrated report by an organization about value creation over time and related communications regarding aspects of value creation" (IIRC, 2013). An integrated report "communicates an organization's strategy, governance, performance, and prospects in the external environment" (IIRC, 2013). Robert G. Eccles opined that integrated reporting presents various issues, including social, environmental, and corporate governance, in one amalgamated report (Eccles \& Saltzman, 2011). To summarise, an organization's future values can be affected by integrated reporting which presents non-financial and financial performance information, such as corporate strategy and governance, environmental, social and economic.

Nowadays, integrated reporting principle is at an early stage in Southeast Asian Countries. For instance, in 2013, the Institute of Singapore Chartered Accountants (ISCA) and the Malaysian Institute of Accountants (MIA) in 2014 created Integrated Reporting Steering Committees (IRSC), which have a vital roles in developing integrated reporting (Abdullah, Husin, \& Nor, 2017). The integrated reporting is still unknown in Malaysia and not yet 


\section{ENTREPRENEURSHIP AND SUSTAINABILITY ISSUES}

ISSN 2345-0282 (online) http://jssidoi.org/jesi/

2020 Volume 7 Number 4 (June)

http://doi.org/10.9770/jesi.2020.7.4(16)

integrated (Graham, 2014; Jamal \& Ghani, 2016). PWC (2014) noted that most of the Top 30 companies listed on the Bursa Malaysia already disclose at least some of the content elements in the international integrated reporting framework (IR framework). However, there is a lack of linkage between these elements. Also, a survey of ISCA and National University of Singapore [NUS] (2014) indicated low level of knowledge about integrated reporting in Singapore but a higher level than the other Southeast Asian countries. Thailand, however, still has voluntary disclosure of integrated financial reporting in the Stock Exchange of Thailand (Suttipun, 2017). Thai listed companies started to integrate financial reporting into their corporate reports in 2015 (Aujirapongpan \& Chanatup, 2015). As the principle of integrated reporting is in its initial stages, it is increasing academic attention.

Although the integration of reporting has been carried out continuously since 2002, a definitive reporting framework is still currently being developed. Internationally IIRC is vital for creating an IR framework (Velte, 2014). IIRC was formed in 2010 through a partnership between GRI and the Prince of Wales Accounting for Sustainability Project (Main \& Hespenheide, 2012. They published their first framework in December 2013. Practitioners should focus on the international integrated reporting framework for the purpose of comparison at that national and international level. Under this framework, the basic concepts and principles of the annual integrated report consist of content elements, guiding principles and fundamental concepts (IIRC, 2013). The details are as follows (Table 1):

Table 1. Summary of international integrated reporting framework

\begin{tabular}{lll}
\hline \multicolumn{1}{c}{ Fundamental Concepts } & \multicolumn{1}{c}{ Guiding Principles } & \multicolumn{1}{c}{ Content Elements } \\
\hline 1. Capitals & 1. Strategic focus and future orientation & $\begin{array}{c}\text { 1. Organizational overview and } \\
\text { external environment }\end{array}$ \\
1.1 Financial & 2. Connectivity of information & 2. Governance \\
1.2 Manufactured & 3. Stakeholder relationships & 3. Business model \\
1.3 Intellectual & 4. Materiality & 4. Risks and opportunities \\
1.4 Human & 5. Conciseness & 5. Strategy and resource allocation \\
1.5 Social and relationship & 6. Reliability and completeness & 6. Performance \\
1.6 Natural & 7. Consistency and comparability & 7. Outlook \\
2. Value creation & & 8. Basis of presentation \\
\hline
\end{tabular}

Source: (Stent \& Dowler, 2015)

\section{Corporate Governance Mechanism and Integrated Financial Reporting}

Corporate governance (CG) is a concept that has existed for centuries. However, the definition is different according to the views of academics. Tricker (1984) mentioned that CG is a control role not related directly to the company's operations creating satisfaction for the supervisory authorities while controlling management. Keasey and Wright (1993) defined corporate governance as 'a structure, process, culture and system that contributes to the successful operation of the organization'. Parkinson (1994) defined CG as 'supervising processes to ensure that the operations of the company are consistent with the interests of shareholders'. Gillan and Starks (1998) found corporate governance was 'a legal system, rules, and factors that control the operations of the company'. OECD (2004) defined CG as 'referring to the company guidance and control system. The structure of CG represented the allocation of rights and responsibilities of various groups in the company such as the board of directors, shareholders and other stakeholders'. It was also determining rules and work processes to be used as a guide in making decisions about business operations. With good governance, the company will have a structure that helps in determining objectives and methods for monitoring performance and achieving objectives. SET (2006) has defined CG as a system that provides a structure and process of relations between shareholders, management team and the board of directors, to "create competitiveness, lead to growth and add value to shareholders in the long term with regard to other stakeholders". From the definition of CG, it can be concluded that CG is controls company operations to achieve objectives in accordance with the interests of stakeholders. 


\section{ENTREPRENEURSHIP AND SUSTAINABILITY ISSUES}

ISSN 2345-0282 (online) http://jssidoi.org/jesi/

2020 Volume 7 Number 4 (June)

http://doi.org/10.9770/jesi.2020.7.4(16)

In the past, CG was "an important mechanism to reduce problems between the management and the shareholders of the company by controlling and monitoring the operations of the management department through the board of directors to create maximum benefits for shareholders" (Lazonick \& O'Sullivan, 2000). However, the current business philosophy changed from taking into account the best benefits of shareholders to consider the benefits of all stakeholders such as the environment, related communities, customers and employees, etc. (Pfarrer, 2010). Therefore, CG must give priority to other stakeholders to maintain the interests of shareholders. It is associated with the objectives of integrated financial reporting that focuses on users of both reports e.g. group of funding providers or shareholders, and other stakeholders. According to the study of Shao (2009) and Mallin, Michelon, and Raggi (2013), it could form a group of CG mechanisms affected business information disclosure into 2 groups. 1) Stakeholder-Oriented CG Mechanism: STCG consists of ownership diversity, board size, nonindependent directors, community directors, environment directors, CSR committees, women directors, and board interlocks. 2) Shareholder-Oriented CG Mechanism: SHCG consists of CEO duality, independent directors, insider ownership, institutional ownership, and ownership concentration.

From the literature review and related research, that the following relationship between the disclosure of business information and the CG-oriented mechanism and. Allegrini and Greco (2013) studied the relationship of CG mechanisms and information disclosure of listed companies in Italy. It found a positive correlation of the disclosure of business information with that the distribution of shares conflicting with Mallin et al. (2013). United States studies of the relationship of social and environmental information disclosure, social performance, and CG mechanisms. The size of the directors has a positive influence on the disclosure of business information while the distribution of shares is negatively correlated with social and environmental information disclosure (Akhtaruddin \& Rouf, 2012; Allegrini \& Greco, 2013; Jizi, Dixon, \& Stratling, 2014; Rouf, 2011). In addition to the distributed shareholding structure and the size of the business, it affects the level of information disclosure of the business. Shao (2009) and Mallin et al. (2013) found that directors who are related to the community, environmental organizations and many companies were an important factor causing an increase in the level of information disclosure of the company. In addition, according to the study of Cai, Keasey, and Short (2006), it was found that the disclosure of business information were positively related to female directors.

In the past, there was a study of the relationship of the shareholder-oriented CG mechanism and business information disclosure. The corporate governance mechanism was an important factor that causes the level of information disclosure to increase and decrease in the same direction and opposite direction with Shao (2009). The study found that if the company shares were held by many institutional investors, the level of information disclosure of the company has decreased as well as holding shares by persons within the company or holding by executives and directors. The independent directors' proportion positively correlates with the disclosure of business information (Arcay \& Vazquez, 2005; Cheng \& Courtenay, 2006; Clemente \& Labat, 2009), and the merger of the Chairman and CEO. It was also an important factor causing the level of information disclosure to increase and decrease (Akhtaruddin \& Rouf, 2012; Gul \& Leung, 2004; Rouf, 2011).

\section{Stakeholder-Oriented Corporate Governance Mechanism and Integrated Financial Reporting}

At present, businesses are facing pressure from economic, social and environmental problems, allowing business owners and executives to increase transparency in operations and consider the impact on society more including efforts to report activities that affect stakeholders of the business. Ullmann (1985) believes that any action of a stakeholder-focused entity would affect the amount of information disclosure that was associated with more stakeholders. According to the study of Sacconi (2006) and Mallin et al. (2013), it was found that the corporate governance mechanism that focuses on stakeholder groups is related to the level of disclosure of qualitative information about the business regarding responsibility for society and environment. According to a study by Churet and Eccles (2014), it found that businesses with good governance, social and environmental, performance affect the integrated financial reporting data disclosure of the business which corresponds to the research results 


\section{ENTREPRENEURSHIP AND SUSTAINABILITY ISSUES}

ISSN 2345-0282 (online) http://jssidoi.org/jesi/

2020 Volume 7 Number 4 (June)

http://doi.org/10.9770/jesi.2020.7.4(16)

of Frias-Aceituno, Rodriguez-Ariza, and Garcia-Sanchez (2014). The results found that the level of disclosure of social responsibility according to GRI's reporting framework affects the integrated financial reporting level of the company. It could be seen that the focus on business stakeholders is related to the integrated financial reporting. The researcher therefore set the research hypothesis as follows:

\section{H1: Focused CG Mechanism Stakeholders are positively related to the Integrated Financial Reporting.}

\section{Shareholder-Oriented Corporate Governance Mechanism and Integrated Financial Reporting}

CG was a mechanism to monitor the operations of the management department to maintain shareholders' best interests (Fama, 1980). The mechanisms reduced agent problems that have a long history. The quality of information disclosure in company reports is affected by Good corporate governance (Williamson, 1981). Most of the research results found that company information disclosure is associated with corporate governance (Arcay \& Vazquez, 2005; Cai et al., 2006; Eng \& Mak, 2003; Gul \& Leung, 2004; Ho \& Wong, 2001; Jizi et al., 2014; Mohamad \& Sulong, 2010; Rouf, 2011). It was consistent with Durak (2013)'s study which found that companies with a strong and diverse regulatory structure of the Board of Directors influence the integrated financial reporting of the business. Although the director had a duty to report the business performance to the shareholders, the CG mechanism would increase the amount of information disclosure and reduce the asymmetry of information between executives and shareholders. However, the corporate governance mechanism had many elements and not all components would have a positive relationship only. Some elements were related in the opposite direction to the level of information disclosure (Mallin et al., 2013).

\section{H2: CG Mechanism focusing on the group of shareholders has a negative relationship to the Integrated Financial Reporting.}

\section{Integrated Financial Reporting and Investment Risk}

Europeans recognized the term risk about 1,200 years ago as a term used to describe uncertainty (Kast \& Lapied, 2006). Frank H. Knight is the first economist to separate the definition of risk and uncertainty clearly. He wrote the book titled "Risk, Uncertainty and Profit" published in 1921 (Holton, 2004). In Knight's view, risk means an event that can predict the outcome of the probability calculation, while uncertainty means an event that cannot predict the outcome because it is impossible to know the probability of the outcome. In 1960, Harry M. Markowitz proposed the theory of securities selection based on risks and rewards rather than receiving (Brigham \& Ehrhardt, 2013). Investment risk is an important factor in investors' investment decisions. The risks can be defined as follows (Thailand Securities Institue, 2013): In general, risk means uncertainty that may result in one of the future opportunities under certain probability levels, and risk from investment. Investment Risk means the opportunity or possibility that investors will not receive the expected return. The stock exchange is a major source of funds for listed companies. Investors can choose to invest in assets based on acceptable risks and returns. Therefore, the listed company is responsible for disclosing information that is relevant to the decision to investors.

In the past, the study of the relationship of the risk of investment in securities and the level of information disclosure of the business and focused on developed countries such as Australia, the United Kingdom and the United States, (Clarkson \& Satterly, 1997; Clarkson \& Thompson, 1990; Firth, 1984). According to Clarkson, Guedes, and Thompson (1996) and Clarkson and Satterly (1997), the level of information disclosure and investment risk associated with each other is in the opposite direction. For developing countries, there were not many studies in this area and there are also different opinions. Lam and Du (2004) studied the relationship of information disclosure and risk from investment in the Chinese stock market. They found that compulsory disclosure is related to investment risks of securities. However, they did not find the relationship of voluntary 
sector disclosure and risk from investment in securities. Hassan, Giorgioni, Romilly, and Power (2011) found the relationship between voluntary disclosure levels and risks from investment in securities through studying Egypt's relationship of voluntary disclosure and investment risks. From this relationship, there is a probability of the relationship between integrated financial reporting and investment risk. The researcher therefore set the research hypothesis as follows:

\section{H3: Integrated Financial Reporting has negative relationships with Investment Risk.}

\section{Conceptual Framework}

The relationships of variables in this study are shown in the conceptual framework in Figure 1. The relationship of stakeholder-oriented corporate governance mechanism is expected to be positive, but negative to integrated financial reporting. Finally, the relationship of integrated financial reporting to investment risk may be negative.

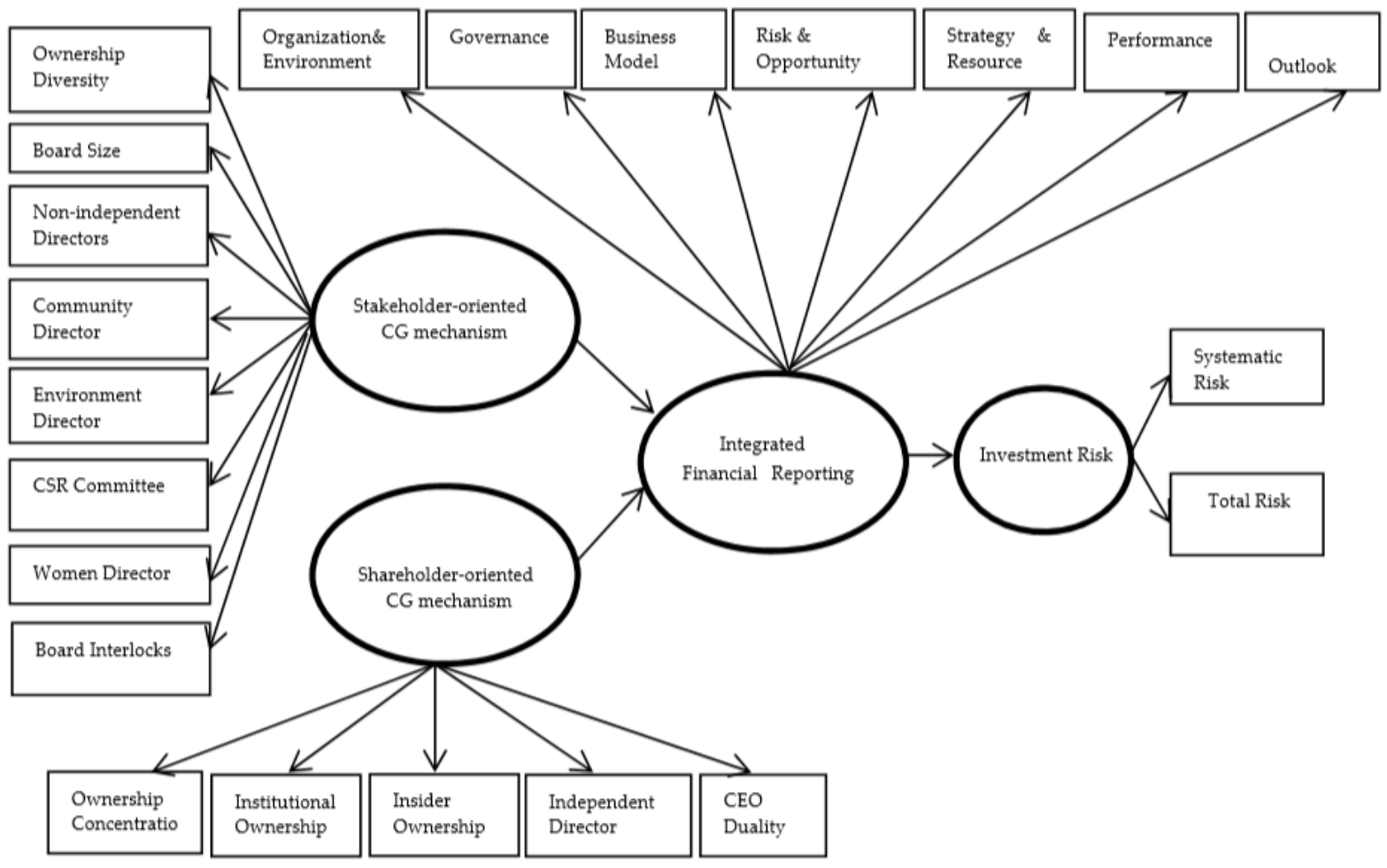

Figure 1. Conceptual framework of the study 


\section{Research Methodology}

\section{Sample and Population}

This study's population consisted of 583 Thai Stock Exchange listed companies in 2015. Of these, 65 were excluded as property funds. In addition, 38 were excluded because of under rehabilitation. This study employed a structural equation modeling (SEM) approach. According to the concept of Bentler and Chou (1987), the number of samples should be 5-10 samples per 1 observed variable. The resulting sample proportion to the observed variable 10:1 was 240 firms. The data were collected from the annual registration statement (Form 56-1) for year-end 2015. This year was chosen because it was the first time that the Securities and Exchange Commission had mandated corporate social responsibility information be disclosed by all listed companies on form 56-1.

\section{The Integrated Financial Reporting Measurement}

The researchers employed the content analysis approach to examine how the corporate reporting of the sample organizations adopted of the IR framework. The level and extent to which integrated financial reporting had been applied in previous studies (Herath \& Gunarathne, 2016; Stent \& Dowler, 2015) was determined using the content elements of the IR framework. In the current study, the basic of presentation element was excluded because it is difficult to be measured objectively. Therefore, the integrated financial reporting index consisted of 34 items across seven categories: business model ( 5 items), strategy and resource allocation (4 items), performance ( 7 items), governance (5 items), organizational overview and external environment ( 7 items), risk and opportunities (3 items), and future outlook (3 items). The researchers applied dichotomous scoring to indicate the level of integrated financial reporting. An item scores one if it is mentioned otherwise it scores zero. Disclosure Index (DI) is calculated by:

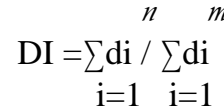

Where;

$\mathrm{di}=1$ if the item is mentioned and 0 if not;

$\mathrm{n}=$ the number of mentioned items;

$\mathrm{m}=$ the maximum number of items;

Disclosure Index takes values between 0 and $1(0 \leq \mathrm{INDEX} \leq 1)$. A value closer to 1 indicated a greater applies the International Integrated Reporting Framework into corporate reporting.

\section{Data Analysis}

Structural equation modelling (SEM) was used due to its superior flexibility and capabilities (Byrne, 2016). The measurement model was examined with confirmatory factor analysis (CFA) and the relationships within the model were examined using path analysis (Kline, 2011). 


\section{Research Finding}

\section{Causal Modeling}

The direct and indirect relation between investment risk and the corporate governance mechanism, through the integrated financial reporting is studied using a structural equation model (SEM). The structural model (Figure 2) shows the relationship among thevariables included in our study. Goodness of fit indicators (Table 1) demonstrate that themeasures selected are consistent with a good fit, including chi-square $194.40(\mathrm{p}=0.10), \mathrm{CMIN} / \mathrm{DF}$ (1.13), GFI (0.97), AGFI (0.96), CFI ( 1.00), NFI (1.00), RMSEA (0.02). Accordingly, this model was generally consistent with empirical data and the rule of model fit.

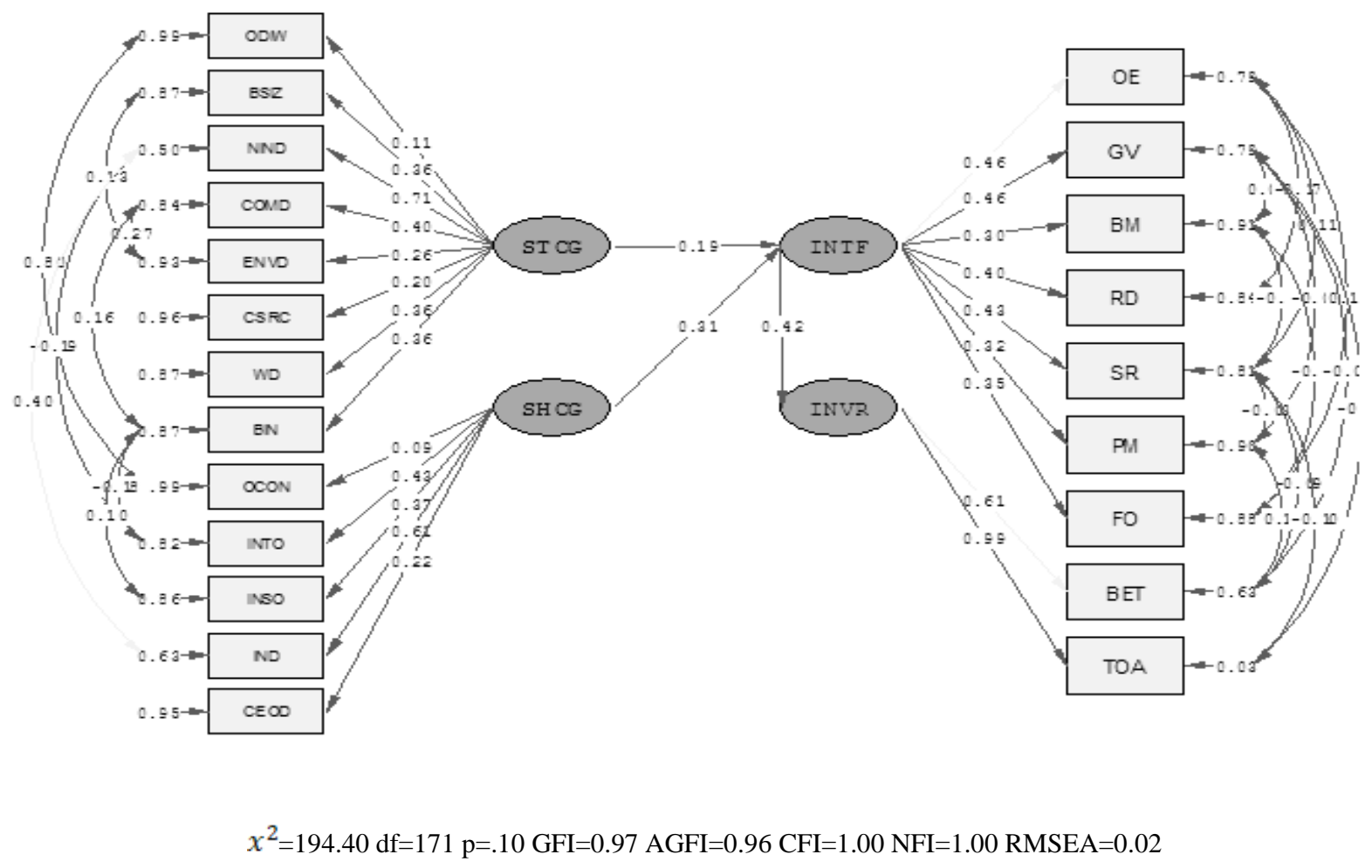

Figure 2. Structural Model

Structural equation modelling, path analysis extended the regression model results, to assess the significance of the proposed relationship paths in the model at $\mathrm{p}<0.05$. Of the proposed factors in integrated financial reporting, both(stakeholder-oriented CG mechanism and shareholder - oriented CG mechanism) had a significant positive relationship. The standardized regression weights indicated that the shareholder-oriented CG mechanism ( $\beta=0.31)$ is higher than than the stakeholder-oriented CG mechnism $(\beta=0.19)$. In addition, the shareholderoriented corporate governance mechanism had a significant positive relationship to investment risk proxies, while the stakeholder-oriented CG mechnism dit notsignificant. The regression weights showed that the shareholderoriented CG mechanism $(\beta=0.13)$ is higher than the stakeholder-oriented CG mechnism $(\beta=0.08)$. Finally, the integrated financial reporting had a significant positive relationship $(\beta=0.42)$ to investment risk. 
ENTREPRENEURSHIP AND SUSTAINABILITY ISSUES

ISSN 2345-0282 (online) http://jssidoi.org/jesi/

2020 Volume 7 Number 4 (June)

http://doi.org/10.9770/jesi.2020.7.4(16)

Table 2. Model effects

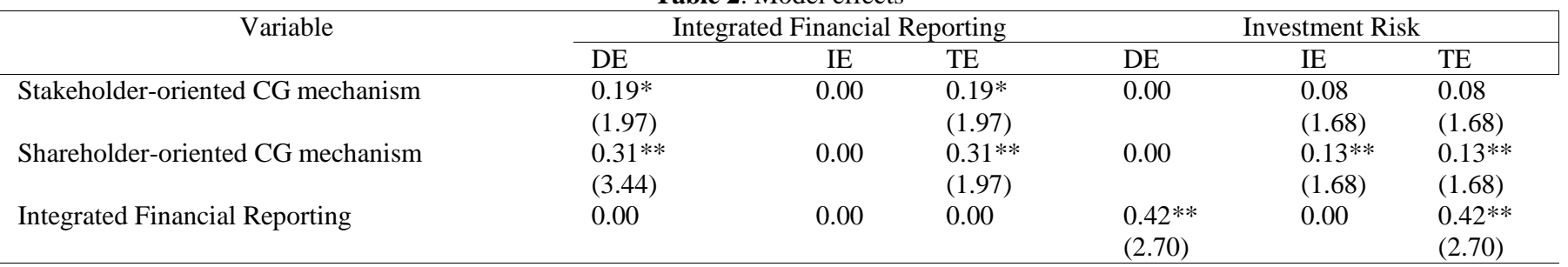

Note: *Level of significance 5\%, ** Level of significance $1 \%$

The model effects (Table 2) show the standardized coefficients and the direct and indirect effects on and statistical significance of the investment risk proxies. From Table 2, it was found that the causal model affecting investment risk was directly influenced by integrated financial reporting variables. It has a positive influence coefficient of 0.42 which is a significant influence statistical at level 0.01. In addition, investment risk variables are indirectly influenced by shareholder-oriented CG mechanisms. It has a positive influence coefficient equal to 0.13 which is the influence of statistical significance at the 0.01 level. Stakeholder governance mechanism has positive influence coefficient at 0.08 . In addition, it can determine the causal model that affects reporting integrated finance as follows:

The causal models affect integrated financial reporting directly influenced from shareholder-oriented corporate governance mechanisms with the highest influence coefficient equal to 0.31 . It is an influence that has statistical significance at level 0.01 and is positively influenced by the stakeholder-oriented corporate governance mechanism with the lowest influence coefficient of 0.19 . It has the influence of statistical significance at the level of 0.05. The predictive coefficient was found that the causal model could explain 18.00 percent of the investment risk $\left(\mathrm{R}^{2}=0.18\right)$. The causal model can together explain 28.00 percent of integrated financial reporting $\left(\mathrm{R}^{2}=0.28\right)$.

\section{Hypothesis Outcomes}

Based on the the analysis of the relationship between shareholder-oriented corporate governance mechanism, corporate governance-oriented stakeholders, integrated financial reporting, and risks from investment of the business by using structural equations modelling (SEM) to test the Measurement Model it is consistent with empirical data. In addition, the variance obtained from the regression analysis can analyze the results of the research hypothesis as follows:

\section{H1: Focused Corporate Governance Mechanism Stakeholders are related positively to the Integrated Financial Reporting.}

From the analysis results, it was found that the stakeholder-oriented corporate governance mechanism had a positive correlation with integrated financial reporting with statistical significance at the level of 0.05 with the positive influence coefficient, the lowest is 0.19 . Therefore the study supports the hypothesis.

\section{H2: Focused Corporate Governance Mechanism, the shareholder group has a negative relationship with Integrated Financial Reporting.}

From the analysis results, it was found that the shareholder-oriented corporate governance mechanism had a positive correlation with integrated financial reporting with statistical significance at 0.01 level with a maximum positive influence coefficient of 0.31 . Therefore, the study results do not support assumptions.

\section{H3: Integrated Financial Reporting has a negative relationship to Investment Risk.}




\section{ENTREPRENEURSHIP AND SUSTAINABILITY ISSUES}

ISSN 2345-0282 (online) http://jssidoi.org/jesi/

2020 Volume 7 Number 4 (June)

http://doi.org/10.9770/jesi.2020.7.4(16)

From the results of the analysis, it was found that integrated financial reporting had a positive correlation with investment risk with statistically significant level 0.01 with a coefficient of influence equal to 0.42 . Therefore, the study results do not support assumptions.

\section{Conclusions}

For analyzing the relationship between factors to prove the hypothesis the researcher used the Lisrel version 8.72 program to analyze using Path Analysis to test all 3 hypotheses. It was found that statistical results support 1 research hypothesis and statistical results do not support 2 research hypotheses. From the analysis of results, it was found that the stakeholder-oriented corporate governance mechanism had a positive correlation with integrated financial reporting with statistical significance at the level of 0.05 with the lowest influence coefficient of 0.19. Therefore, the study results support the assumptions. In accordance with Sacconi (2006) and Mallin et al. (2013) studies found that stakeholders-oriented corporate governance mechanisms relate to the level of qualitative information disclosure of businesses, especially the disclosure of social and environmental responsibility.

In addition, businesses with environmental, social and good corporate governance performance are associated with the disclosure of integrated financial information for businesses (Churet \& Eccles, 2014). The level of social responsibility disclosure according to the Global Reporting Initiative (GRI) influences the level of integrated financial reporting of the company. The focus of corporate governance mechanisms on stakeholders has a positive influence on integrated financial reporting. It may be caused by such corporate governance mechanisms giving priority to stakeholders and having an effort to communicate to stakeholders about the overall business performance by presenting financial performance reports and non-financial performance in one integrated financial report. From the analysis results, it was found that the shareholder-oriented corporate governance mechanism had a positive correlation with integrated financial reporting with statistical significance at 0.01 level with the maximum influence coefficient of 0.31 . Therefore, the study results do not support assumptions. It is in conflict with the findings of Mallin et al. (2013) that found that the shareholder-oriented corporate governance mechanism is in the opposite direction to the level of disclosure of the business.

This research found a similar relationship between the shareholder-oriented corporate governance mechanism and integrated financial reporting. Due to the integrated financial reporting, the focus is on the disclosure of holistic performance data to stakeholders who are the funding providers, primarily investors and shareholders. Therefore, the shareholder-oriented corporate governance mechanism, which gives priority to maintaining benefits for shareholders has a positive influence on the level of integrated financial work. From the results of the analysis, it was found that the integrated financial reporting had a positive correlation with investment risk with statistically significant level at 0.01 , with the influence coefficient equal to 0.42 . Therefore, the study results do not support assumptions. The results of this research are consistent with the studies of Hassan et al. (2011) which found the relationship between voluntary disclosure of business and investment risks in Egypt. But there is a conflict with Lam and Du (2004)'s study that does not find a relationship between voluntary disclosure and investment risks.

However, the finding that compulsory disclosure to the risk of investing in the Chinese stock market also contradicts the results of Clarkson et al. (1996) and Clarkson and Satterly (1997) which found that the disclosure of the business has a negative relationship with the risk of investing in the United States United Kingdom and Austria. This research found a positive relationship between integrated financial reporting and investment risk. It is because the sample group has a high level of risk exposure and business opportunity. Such factors may affect the behavior of investors who are sensitive to information and affect the confidence of investors. The researcher summarizes the results of analyzing the relationship between factors and proof of assumptions as follows. Stakeholder-oriented corporate governance mechanisms and corporate governance-oriented mechanisms for shareholders are positively related to the level of integrated financial reporting, and integrated financial reporting has positive correlations with the investment risk of the sample that is listed on the Stock Exchange of Thailand. 


\section{ENTREPRENEURSHIP AND SUSTAINABILITY ISSUES}

ISSN 2345-0282 (online) http://jssidoi.org/jesi/

2020 Volume 7 Number 4 (June)

http://doi.org/10.9770/jesi.2020.7.4(16)

\section{References}

Abdullah, N. W., Husin, N. M., \& Nor, M. M. (2017). An exploratory study of integrated reporting: A case of public listed companies in Southeast Asia. International Journal of Applied Business and Economic Research, 15(21), 199-205.

http://serialsjournals.com/abstract/25739_ch_22_f_-_ijaber-03.pdf

Abeysekera, I. (2013). A template for integrated reporting. Journal of Intellectual Capital, 14(2), 227-245.

https://ro.uow.edu.au/cgi/viewcontent.cgi?article=3928\&context=commpapers

Akhtaruddin, M., \& Rouf, A. (2012). Corporate governance, cultural factors and voluntary disclosure: Evidence from selected companies in Bangladesh. Corporate Board: Role, Duties and Composition, 8(1), 48-60.https://papers.ssrn.com/sol3/papers.cfm?abstract id=2565253

Allegrini, M., \& Greco, G. (2013). Corporate boards, audit committees and voluntary disclosure: evidence from Italian Listed Companies. Journal of Management \& Governance, 17(1), 187-216. http://doi.org/10.1007/s10997-011-9168-3

Arcay, M. R. B., \& Vazquez, M. F. M. (2005). Corporate characteristics, governance rules and the extent of voluntary disclosure in Spain. Advances in Accounting, 21, 299-331. https://doi.org/10.1016/S0882-6110(05)21013-1

Aujirapongpan, S., \& Chanatup, S. (2015). Integrated Reporting: New Dimension of Firms' Performance Reporting. AU-GSB e-JOURNAL, 8(1). http://www.assumptionjournal.au.edu/index.php/AU-GSB/article/view/1455/1279

Bentler, P.M., \& Chou, C.P. (1987). Practical issues in structural modelling. Sciological Methods \& Research. 16(1).78-117. https://doi.org/10.1177/0049124187016001004

Brigham, E. F., \& Ehrhardt, M. C. (2013). Financial management: Theory \& practice. USA: Nelson Education.

Byrne, B. M. (2016). Structural Equation Modeling with AMOS: Basic concepts, applications and programming. New York: Routledge.

Cai, C. X., Keasey, K., \& Short, H. (2006). Corporate governance and information efficiency in security markets. European Financial Management, 12(5), 763-787. https://dx.doi.org/10.1111/j.1468-036X.2006.00276.x

Cheng, E. C. M., \& Courtenay, S. M. (2006). Board composition, regulatory regime and voluntary disclosure. The International Journal of Accounting, 41(262-289). https://ideas.repec.org/a/eee/accoun/v41y2006i3p262-289.html

Churet, C., \& Eccles, R. G. (2014). Integrated reporting, quality of management, and financial performance. Journal of Applied Corporate Finance, 26(1), 56-64.https://doi.org/10.1111/jacf.12054

Clarkson, P., Guedes, J., \& Thompson, R. (1996). On the diversification, observability, and measurement of estimation risk. Journal of Financial and Quantitative Analysis, 31(1), 69-84. http://doi.org/10.2307/2331387

Clarkson, P. M., \& Satterly, A. (1997). Australian evidence on the pricing of estimation risk. Pacific-Basin Finance Journal, 5(3), $281-299$. https://doi.org/10.1016/S0927-538X(97)00009-7

Clarkson, P. M., \& Thompson, R. (1990). Empirical estimates of beta when investors face estimation risk. The Journal of Finance, 45(2), 431-453. https://doi.org/10.1111/j.1540-6261.1990.tb03697.x

Clemente, A. G., \& Labat, B. N. (2009). Corporate governance mechanisms and voluntary disclosure: The role of independent directors in the boards of listed Spanish firms. International Journal of Accounting Information Systems, 5, 5-24.

https://webs.ucm.es/centros/cont/descargas/documento16048.pdf

Demirel, B., \& Erol, I. (2016). Investigation of integrated reporting as a new approach of corporate reporting. International Journal of Business and Social Research, 6(10), 32-46. https://thejournalofbusiness.org/index.php/site/article/view/1002

Durak, M. G. (2013). Factors affecting the companies' preferences on integrated reporting. International Journal of Contemporary Economics and Administrative Sciences, 3(3-4), 68-85. http://www.ijceas.com/index.php/ijceas/article/view/86/pdf

Eccles, R. G., \& Saltzman, D. (2011). Achieving sustainability through integrated reporting. Stanford Social Innovation Review(Summer), 55-61. https://pdfs.semanticscholar.org/618f/901ec8d9c8b6dc62a3c0344bb303de86e981.pdf 


\section{ENTREPRENEURSHIP AND SUSTAINABILITY ISSUES}

ISSN 2345-0282 (online) http://jssidoi.org/jesi/

2020 Volume 7 Number 4 (June)

http://doi.org/10.9770/jesi.2020.7.4(16)

Eng, L. L., \& Mak, Y. T. (2003). Corporate governance and voluntary disclosure. Journal of Accounting and Public Policy, 22, $325-345$. https://doi.org/10.1016/S0278-4254(03)00037-1

Fama, E. F. (1980). Agency problems and the theory of the firm. The Journal of Political Economy, 88(2), 288-307. https://www.jstor.org/stable/1837292?seq=1\#page_scan_tab_contents

Firth, M. (1984). The extent of voluntary disclosure in corporate annual reports and its association with security risk measures. Applied Economics, 16(2), 269-277. https://doi.org/10.1080/00036848400000036

Frias-Aceituno, J. V., Rodriguez-Ariza, L., \& Garcia-Sanchez, I. M. (2014). Explanatory factors of integrated sustainability and financial reporting. Business strategy and the environment, 23(1), 56-72. https://doi.org/10.1002/bse.1765

Gillan, S., \& Starks, L. T. (1998). A survey of shareholder activism: Motivation and empirical evidence Contemporary Finance Digest, 2(3), 10-34. https://dx.doi.org/10.2139/ssrn.663523

Graham, M. (2014). EY's excellence in integrated reporting awards 2014. Johannesburg: EY. https://cdn.24.co.za/files/Cms/General/d/575/ddb09270c5c544238d1efc43381c9b78.pdf

Gul, F. A., \& Leung, S. (2004). Board leadership, outside directors' expertise and voluntary corporate disclosures. Journal of Accounting and Public Policy, 23, 351-379. http://citeseerx.ist.psu.edu/viewdoc/download?doi=10.1.1.545.2903\&rep=rep1\&type=pdf

Hassan, O. A. G., Giorgioni, G., Romilly, P., \& David M. Power. (2011). Voluntary disclosure and risk in an emerging market. Journal of Accounting in Emerging Economies, 1(1), 33-52. https://doi.org/10.1108/20421161111107840

Herath, R., \& Gunarathne, N. (2016). Assessing the gap between integrated reporting and current integrated corporate reporting practice: A proposed checklist. Paper presented at the 11 th Faculty of Management Studies and Commerce (FMSC) Research Symposium, Sri Lanka.http://dr.lib.sjp.ac.lk/bitstream/handle/123456789/4502/Assessing\%20the\%20Gap\%20between\%20Integrated\%20Reporting\%20and $\% 20$ Current $\% 20$ Integrated $\% 20$ Corporate $\% 20$ Reporting $\% 20$ Practice $\% 20 \mathrm{~A} \% 20$ Proposed $\% 20$ Checklist.pdf? sequence $=1 \&$ is Allowed $=\mathrm{y}$

Ho, S. S. M., \& Wong, K. S. (2001). A study of the relationship between corporate governance structures and the extent of voluntary disclosure. Journal of International Accounting, Auditing \& Taxation, 10, 139-156. https://doi.org/10.1016/S1061-9518(01)00041-6

Holton, G. A. (2004). Defining risk. Financial Analysts Journal, 60(6), 19-25. https://www.glynholton.com/wpcontent/uploads/papers/risk.pdf

Institute of Singapore Chartered Accountants [ISCA], \& National University of Singapore [NUS]. (2014). ISCA-NUS integrated reporting survey 2014. Retrieved April 28, 2017 from https://isca.org.sg/media/775709/isca-nus-integrated-reporting-survey-2014.pdf

Integrated Reporting Committee [IRC]. (2011). Framework for integrated reporting and the integrated report. Discussion Paper. Retrieved January 18, 2017 from http://www.chartsec.co.za/documents/latestNews/IRCOfSAIntergratedReportingGuideJan11.pdf

International Integrated Reporting Council [IIRC]. (2013). Basic for conclusions international <IR> framework. UK: IIRC. https://integratedreporting.org/wp-content/uploads/2013/12/13-12-08-THE-INTERNATIONAL-IR-FRAMEWORK-2-1.pdf

Jamal, J., \& Ghani, E. K. (2016). Integrated reporting practices among real property listed companies in Malaysia. Malaysian Accounting Review, 15(1), 251-274. http://arionline.uitm.edu.my/ojs/index.php/MAR/article/view/571

Jizi, M. I., Dixon, A. S. R., \& Stratling, R. (2014). Corporate governance and corporate social responsibility disclosure: Evidence from the US banking sector. Journal of Business Ethics, 125(4), 601-615. http://dx.doi.org/10.1007/s10551-013-1929-2

Kast, R., \& Lapied, A. (2006). Economics and Finance of Risk and of the Future. England: John Wiley \& Sons.

Keasey, K., \& Wright, M. (1993). Issues in corporate accountability and governance. Accounting and Business Research Vol. 23, Iss. sup1, 1993, 23(91A), 291-303. https://doi.org/10.1080/00014788.1993.9729897

Kline, R. B. (2011). Principles and Practice of Structural Equation Modeling. New York: Guilford Press.

Lam, S., \& Du, J. (2004). Information asymmetry and estimation risk: preliminary evidence from Chinese equity markets. Pacific-Basin Finance Journal, 12(3), 311-331. https://papers.ssrn.com/sol3/papers.cfm?abstract_id=934490 


\section{ENTREPRENEURSHIP AND SUSTAINABILITY ISSUES}

ISSN 2345-0282 (online) http://jssidoi.org/jesi/

2020 Volume 7 Number 4 (June)

http://doi.org/10.9770/jesi.2020.7.4(16)

Lazonick, W., \& O’Sullivan, M. (2000). Maximizing shareholder value: a new ideology for corporate governance. Economy and Society, 29(1), 13-35. https://doi.org/10.1080/030851400360541

Main, N., \& Hespenheide, E. (2012). The integrated reporting: The new big picture. Deloitte Review(10), 124-137. https://www2.deloitte.com/us/en/insights/deloitte-review/issue-10/integrated-reporting-the-new-big-picture.html

Mallin, C., Michelon, G., \& Raggi, D. (2013). Monitoring intensity and stakeholders' orientation: how does governance affect social and environmental disclosure? Journal of Business Ethics, 114(1), 29-43. https://doi.org/10.1007/s10551-012-1324-4

Mohamad, W. I. A. W., \& Sulong, Z. (2010). Corporate governance mechanisms and extent of disclosure: Evidence from listed companies in Malaysia. International Business Research, 3(4), 216-228.

http://citeseerx.ist.psu.edu/viewdoc/download?doi=10.1.1.665.3450\&rep=rep1\&type=pdf

Organisation for Economic Co-operation and Development [OECD]. (2004). OECD principles of corporate governance. 2004. Retrieved December 12, 2016 from http://www.oecd.org/corporate/ca/corporategovernanceprinciples/31557724.pdf

Parkinson, J. E. (1994). Corporate power and responsibility: Issues in the theory of company law. UK: Oxford Clarendon Press.

Pfarrer, M. D. (2010). What is the Purpose of the Firm?: Shareholder and Stakeholder Theories. New York: Routledge.

PricewaterhouseCoopers [PWC]. (2014). The state of integrated reporting in Malaysia. Retrieved April 28, 2017 from

https://www.pwc.com/my/en/assets/publications/the-state-of-integrated-reporting-in-malaysia.pdf

Rouf, A. (2011). Corporate characteristics, governance attributes and the extent of voluntary disclosure in Bangladesh. African Journal of Business Management, 5(19), 7836-7845. http://doi.org/10.5897/AJBM10.1180

Sacconi, L. (2006). A social contract account for CSR as an extended model of corporate governance (I): Rational bargaining and justification. Journal of Business Ethics, 68(3), 259-281. http://doi.org/10.1007/s10551-006-9014-8

Shao, G. (2009). Toward astakeholder model of corporate governance: Evidence from U.S. media companies. (Doctor of Philosophy), University of Alabama, Tuscaloosa, Alabama. https://pdfs.semanticscholar.org/cb98/a616dd90b6eafbddd886f8117a122d2e6ad0.pdf

Stent, W., \& Dowler, T. (2015). Early assessments of the gap between integrated reporting and current corporate reporting. Meditari Accountancy Research, 23(1), 92-117. http://doi.org/10.1108/medar-02-2014-0026

Stock Exchange of Thailand. (2006). The principles of good corporate governance for listed companies. Retrieved March 26,2017 from https://www.set.or.th/sustainable_dev/th/cg/files/2013/CGPrinciple2012Thai-Eng.pdf

Suttipun, M. (2017). The effect of integrated reporting on corporate financial performance: Evidence from Thailand. Corporate Ownership and Control, 15(1), 133-142. http://doi.org/10.22495/cocv15i1art13

Thailand Securities Institue. (2013). Financial market and securities investment for securities investment consultant. Bangkok, Thailand: The Stock Exchange of Thailand. https://market.sec.or.th/public/orap/IC03.aspx?lang=en\&CompRunCode=0000000796

Tricker, R. I. (1984). Corporate governance: practices, procedures, and powers in British companies. Aldershot, UK: Gower Publishing.

Ullmann, A. A. (1985). Data in search of a theory: A critical examination of the relationships among social performances, social disclosure, and economic performance of U.S. firms. Academy of Management. The Academy of Management Review((pre-1986)), 540-556.

http://doi.org/10.2307/258135

Velte, P. (2014). Improving corporate governance quality though modern controlling - Integrated reporting in the german two tier system. Business and Economics Journal, 5(1). http://doi.org/10.4172/2151-6219.1000e103

Williamson, O. E. (1981). The modern corporation: origins, evolution, attributes. Journal of Economic Literature, 19(4), $1537-1568$. https://www.jstor.org/stable/2724566?seq=1\#page scan tab contents 


\section{ENTREPRENEURSHIP AND SUSTAINABILITY ISSUES}

ISSN 2345-0282 (online) http://jssidoi.org/jesi/

2020 Volume 7 Number 4 (June)

http://doi.org/10.9770/jesi.2020.7.4(16)

\section{Acknowledgements}

This research was partially supported by the new strategic research $(P 2 P)$ project, Walailak University, Thailand, (CGSP2P-2562-052). And it also was supported by Institute of Research and Innovation, Walailak University.

Sarapee CHANATUP, Ph.D., is a senior lecturer of Accounting Department, Faculty of Management Sciences, Surathani Rajabhat University, 84000, Surat Thani, Thailand. She received her Ph.D. in business administration from Walailak University. Her publications have appeared in various national academic journals about financial reporting.

ORCID ID: orcid.org/0000-0002-7996-2960

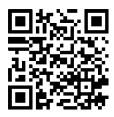

Somnuk AUJIRAPONGPAN, Ph.D., is an associate professor in accounting and director of graduate study in innovation management and business development, School of Management, Walailak University, Thailand. He received his Ph.D. in technopreneurship and innovation management from Chulalongkorn University. His professional expertises are managerial accounting, cost accounting, knowledge management, innovation management and entrepreneurship development. His publications have appeared in various national and international academic journals about accounting, entrepreneurship and business management. He also is a corresponding author of this article who provides the intellectual input, designs and approves the protocols to be followed in the study.

ORCID ID: orcid.org/0000-0001-6275-9053

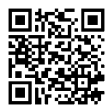

Supit RITKAEW, Ph.D., is an assistant professor in applied mathematics of Innovation Management and Business Development Graduate Study Program of Walailak University. He received his Ph.D. in applied mathematics from University of Innsbruck, Austria. His publications have appeared in various national academic journals about business analytics.

ORCID ID: orcid.org/0000-0003-0543-7730

Copyright (C) 2020 by author(s) and VsI Entrepreneurship and Sustainability Center

This work is licensed under the Creative Commons Attribution International License (CC BY).

http://creativecommons.org/licenses/by/4.0/

cC) (i) Open Access 